\title{
Capital Structure and Firm Efficiency of Non Financial Institutions in Nepal
}

\author{
Bhupal Jaishi* \\ Resam Lal Poudel**
}

\begin{abstract}
Capital structure and firm's efficiency of non-financial companies of Nepal is a less explored research in the Nepalese context. The paper examines the relationship between leverage and efficiency of non-financial firms in Nepal. This paper employs descriptive as well as casual research design to examine the general structure of leverage and efficiency and their relationship too. Secondary data were employed for the study which was extracted from the annual report of respective companies with 60 observations ranging from two to 14 years. The non-financial institution listed in Nepal Stock Exchange is the population of the study. Fifteen companies representing one from trading, three from the hotel sector, five from manufacturing, six from hydro were selected as the sample for the study employing stratified cum purposive sampling method. The variables namely size, tangibility, growth, profitability, leverage and efficiency were analyzed. Descriptive as well as regression analysis was used to assess the relationship among the variables. Different models were used to test the hypothesis. Most of the Nepalese non-financial institution employs both debt and equity in their capital formation. The firms having high leverage are less efficient and more efficient firms' use low leverage. Nepalese non-financial institutions increase in size, investment intangible assets and profitability does not necessarily increase the efficiency of the firms. The positive relationship between efficiency and tangibility justify that more investment in tangible assets increases the firm's efficiency. An increase in sales increases the growth rate of nonfinancial firms as suggested by the positive relationship between size and growth. There is no consistency on the impact of size, tangibility, profitability, and growth on leverage among four industries within nonfinancial firms. The major conclusion of this study is that size, tangibility, profitability, and growth are the significant factors in determining the efficiency and leverage of Nepalese non-financial firms. The firms having high leverage are less efficient and more efficient firms use low leverage.
\end{abstract}

Keywords: Capital structure, efficiency, non-financial, profitability, tangibility.

\section{INTRODUCTION}

Efficiency consists of two main components; technical efficiency and allocative efficiency (Coelli, Rao, \& Battese, 1998). Generally, the term efficiency refers to technical efficiency. Technical efficiency occurs if a firm obtains maximum output from a set of inputs. Allocative efficiency occurs when a firm chooses the optimal combination of inputs, given the level of prices and the production technology (Coelli, Rao, et al., 1998; Rogers 1998). There is a general understanding that a firm is allocatively inefficient when a firm fails to choose the optimal combination of inputs at a given level price (Coelli, Rao, et al., 1998). The firm is efficient when it achieves maximum output from a particular input. Capital structure is thus associated with the level of efficiency too.

*Mr. Jaishi is Lecturer in Faculty of Management, Prithvi Narayan Campus, Tribhuvan University.

**Mr. Poudel is Lecturer in Faculty of Management, Prithvi Narayan Campus, Tribhuvan University

Corresponding author: Bhupal Jaishi.Email:bpl.jaishi@gmail.com 
The capital structure decision is critical for the continued existence of any business organization so as to maximize returns to stakeholders (Akintoye, 2008). Many studies have been carried out to investigate the relationship that exists between financial leverage and firm efficiency (Warokka, Herrera, \& Abdullah, 2011). Some studies revealed a positive relationship between capital structure and efficiency (Akintoye, 2008; Dare \& Sola, 2010), while others reported a negative relationship between capital structure and efficiency (Iorpev \& Kwanum 2012). However, some studies indicated that there is no relationship between capital structure and efficiency (Prahlathan \&Rajan, 2011).

Non-financial institutions principally engaged in the production of market goods and non-financial services and their financial transactions are wholly distinct from those of their owners. Non-financial corporations are broadly classified as private and public corporations, holding companies, nonprofits or associations. The study is concerned with the examination of capital structure position, the position of efficiency and impact of size, tangibility, profitability, and growth on efficiency and leverage. The model has been developed to examine the relationship between capital structure and firm efficiency. These models are based upon the literature of developed countries. Whether these models are applicable in listed non-financial companies of Nepal or not? It is the major issue of the study.

The study regarding capital structure and firm efficiency in Nepalese enterprises helps in identifying the potential problems in capital structure and firm efficiency. The capital structure remains a controversial issue in modern corporate finance. The non-financial industry is a vital part of the entire financial system. Apart from the financial institution, non-financial companies contribute significantly to the financial intermediation of the economy. As such, their success means the success of the economy; their failure means failure to the economy (Ansah-Adu, Andoh, \& Abor, 2012). Friend and Lang (1988) found a significantly negative relation between profitability and debt/asset ratios. Hence, these types of research findings will be benefited in determining the capital structure to achieve the optimum level of a firm's efficiency. The major objective is to assess the relationship between capital structure and firm's efficiency of non-financial institutions listed companies in Nepal.

\section{LITERATURE REVIEW}

Saeedi and Mahmoodi (2011) examined the relationship between capital structure and firm performance of 320 firms listed on the Tehran Stock Exchange. The empirical research concludes that there is a negative relationship between capital structure and return on assets, on the other hand, there is no significant relationship between capital structure on return on equity. The study conducted by Ahmad, Haq, Nasir, Ali, and Ullah, (2001) findings indicate that assets tangibility and firm size have a significant and positive relationship with debt ratio whereas there is a significant negative relationship between liquidity and debt ratio. Opoku, Adu, and Anarfi, (2013) studied the impact of capital structure on profitability in the Ghanaian Stock Exchange, the study reveals that there is a negative relationship between leverage and profitability among the listed banks. The bank size has a negative relationship on profitability.

Many studies have had conflicting views on the impact related to capital structure and financial performance. Taub (1975) found that the return to the firm, long term rate of interest and size of the firm revealed a positive influence on the firm's debt-equity ratio. Zeitun and Tian (2007) showed that all the capital structure variables including short term debt, total debt, long term debt and total equity have a significantly negative impact on firm performance. Yahyazadehfar, Shams, and Matan, (2010) reveal that there was a negative and meaningful relationship between the debt ratio of the company and assets' 
structure, profitability and market value to book value. Saeedi and Mahmoodi (2011) showed that earning per share (EPS) is significantly and positively associated with capital structure. However, return on assets (ROA) is negatively associated with capital structure. Pouraghajan, Malekian, Emamgholipour, Lotfollahpour, and Bagheri, (2012) found that there is a significant negative relationship between debt ratio and financial performance of companies, and a significant positive relationship between asset turnover, firm size, asset tangibility ratio, and growth opportunities with financial performance measures. Dogan (2013) exhibits that the financial leverage ratio negatively affects profitability as measured by ROA whereas firm size has a positive impact on the firm's profitability. Idode, Adeleke, Ogunlowore, and Ashogbon (2014) examined that capital structure has a significant positive influence on profitability. Chechet and Olayiwola (2014) reveal that the debt ratio is negatively related to profitability and equity has a significant and positive impact on firm performance. Kazempour, and Aghaei (2015) showed a significant positive relationship between capital structure and firm performance.

In the context of Nepal, few studies have been carried out on the relationship between capital structure and financial performance of Nepalese firms. Poudel (1994) found that the study observed that size and growth were positively related to leverage and risk, profitability and assets structure were negatively related to leverage. Basnet (2015) concluded that standard determinants of banks' capital structure do affect the market leverage of the banks and capital structure theories- trade-off and pecking order are complementary for the Nepalese commercial banks. Bhattarai (2016) concluded that capital structure significantly negatively affects the firm performance of Nepalese manufacturing companies. Maharjan (2017) found that long term debt to equity ratio, total debt to equity ratio, bank size, and liquidity position is negatively related to firm performance. However, there is a positive relationship between credit risk with firm performance.

The importance of this study may be viewed from its contribution to filling an important gap in the literature and also findings of this study can add value to the existing body of the literature. Nevertheless, most of the study concentrated on examining the impact of capital structure on firm efficiency on financial firms but the study on non-financial firms needs to be addressed in the Nepalese context. However, the study has been conducted on the manufacturing firms which are also part of non-financial institutions too. Empirical research on trading, hotels, hydro are less addressed in prior research. This study, therefore, will address the research gap on the same.

\section{DATA AND METHODS}

\subsection{Research Design}

This study has employed descriptive and causal-comparative research designs. The descriptive research design has been adopted for fact-finding and adequate information gathering about the fundamental issues associated with capital structure and firm efficiency variables of Nepalese nonfinancial companies. It explains the real and actual condition, situation and facts. The study also used a causal-comparative research design to establish the cause and effect relationship between capital structure and firm efficiency of Nepalese non-financial companies.

\subsection{Nature and Sources of Data}

The study is based on secondary data. The data on different independent and dependent variables were collected from the published reports of listed non-financial firms. The debt and equity composition, operating income, net profit after tax (NPAT), sales data were collected and further analyzed. 


\subsection{Sample and Sampling Procedure}

The universe of the study comprises of all the non-financial companies listed at Nepal Stock Exchange (NEPSE). The sampling frame for the study consists of the non-financial institution list of the companies listed at NEPSE as of 15th July 2018. The sampling criteria requirement for selection of the listed firms as the study sample units for the period of 2 to 14 years starting from 2004/05 to 2017/18. Hence, out of 49 non-financial listed companies as on 15th July 2018, a stratified purposive sampling technique has been used to select sample units. The stratification variable comprises industry sectors. The NEPSE publishes sub-indices for commercial firms, development firms, finance companies, hotels, hydropower, insurance, manufacturing and processing, and others. Among the sectors classified, non-financial institutions namely hydro, hotels, trading and manufacturing sectors selected as major sample industries. The industry categorized as others by NEPSE has been excluded from the sample. The final sample comprises of 15 listed non-financial companies which represent around 31 percent of the population and comprise of 6 hydro, three hotels, one trading, and five manufacturing companies. The basis for the selection of sample firms is purposive depending on the availability of published annual reports and sampling criteria.

\subsection{Data Analysis Tools}

Descriptive, correlation and regression methods of analysis have been employed in the study. The descriptive statistics contain mean, standard deviation, minimum and maximum values of variables used to explain the characteristics of sample firms. The correlation analysis is used to measure the direction and magnitude of the relationship between dependent and independent variables. The regression analysis is used to find out the influence of the independent variable over the dependent variable solely and combined with other variables. Those data were analyzed with the help of the Ms-Excel office package and other statistical software. The output of the analyzed data was presented in the table and figures as and when necessary.

The econometric models employed in this study attempts to analyze the relationship between capital structure and firm efficiency. The following regression models have been used in this study to examine the relationship between leverage and firm's efficiency of Nepalese non-financial institutions. Thus, the following model equation is designed to test the hypothesis.

From the conceptual framework the function of dependent variables (efficiency and leverage) takes the following form:

EFFICIENCY $=f($ SIZE, TAN, PROF, GTH).

LEVERAGE $=f($ SIZE, TAN, PROF, GTH).

More specifically, the given model has been segmented into the following models:

The model estimated in the study assumes that efficiency (EFF) and leverage (LEV) are the dependent variables and size $[\ln ($ sales) $]$, tangibility (TAN), profitability (PROF) and growth in sales (GROWTH) are independent variables. To analyze the impact of independent variables on dependent variables the model has been developed on the sector-wise basis and variable wise basis. Hence the models are as follows:

\section{First Model}

In this model, the dependent variable is efficiency (EFF) indicated by total output to total inputs. Size, tangibility, profitability, and growth are independent variables that are tested on efficiency. The model is presented as follows:

$\mathrm{EFF}=\beta_{0}+\beta_{1} \mathrm{SIZE}+\beta_{2} \mathrm{TAN}+\beta_{3} \mathrm{PROF}+\beta_{4} \mathrm{GROWTH}+\mathrm{e}$. 


\section{Second Model}

In this model, the dependent variable is efficiency (EFF) indicated by total output to total inputs. Leverage, size, tangibility, profitability, and growth are independent variables that are tested on efficiency. The model is presented as follows:

$\mathrm{EFF}=\beta_{0}+\beta_{1} \mathrm{LEV}+\beta_{2} \mathrm{SIZE}+\beta_{3} \mathrm{TAN}+\beta_{4} \mathrm{PROF}+\beta_{5} \mathrm{GROWTH}+\mathrm{e}$.

\section{Third Model}

In this model, the dependent variable is leverage (LEV) indicated by total debt to total assets. Size, tangibility, profitability, and growth are independent variables that are tested on leverage. The model is presented as follows:

$\mathrm{LEV}=\beta_{0}+\beta_{1} \mathrm{SIZE}+\beta_{2} \mathrm{TAN}+\beta_{3} \mathrm{PROF}+\beta_{4} \mathrm{GROWTH}+\mathrm{e}$.

\section{Fourth Model}

In this model, the dependent variable is leverage (LEV) indicated by total debt to total assets. Size, tangibility, profitability, and growth are independent variables that are tested on leverage. The model is presented as follows:

\section{$\mathrm{LEV}=\beta_{0}+\beta_{1} \mathrm{EFF}+\beta_{2} \mathrm{SIZE}+\beta_{3} \mathrm{TAN}+\beta_{4} \mathrm{PROF}+\beta_{5} \mathrm{GROWTH}+\mathrm{e}$.}

Multicollinearity can also be identified by the Variance Inflation Factor (VIF) technique, which is a statistic calculated for each variable in the model. Theoretically, a VIF greater than 10 may suggest that the concerned variable is multi-collinear with others in the model and may need to be excluded from the model. None of the VIFs is high, it suggests that there were no issues on strong collinearity between the variables as the VIFs does not exceed 3 in the study.

\section{RESULTS AND DISCUSSION}

Equity and debt are the sources of funds used by business firms for investment. The composition of equity and debt designed to manage total assets is capital structure. An optimal mix of these sources maximizes shareholder's equity. It means optimal capital structure support to maximize shareholder's wealth. Whether there is an optimal capital structure or not? It is one of the controversial issues as per available literature. The composition of assets and capital structure components in nonfinancial listed companies of Nepal are presented and analyzed with the help of financial ratios in this section.

Table 1

Financial Ratios (Percentage of Total Assets)

\begin{tabular}{lrrrrrr}
\hline Assets & Hotel & Mfg & Hydro & Trading & Mean & SD \\
\hline Current assets & 0.29 & 0.49 & 0.15 & 0.65 & 0.42 & 0.19 \\
Tangible assets & 0.71 & 0.51 & 0.71 & 0.35 & 0.54 & 0.15 \\
Other assets & 0 & 0 & 0.14 & 0 & 0.04 & 0.06 \\
Owner`s equity & 0.57 & 0.42 & 0.84 & 0.26 & 0.5 & 0.21 \\
Long term debt & 0.16 & 0.08 & 0.13 & 0.06 & 0.1 & 0.04 \\
\hline Current liabilities & 0.27 & 0.5 & 0.03 & 0.68 & 0.4 & 0.24 \\
\hline
\end{tabular}


The position of capital structure and assets structure as presented in Table 1 indicates that the trading companies have used a maximum of 74 percent of total debt financing followed by manufacturing companies 58 percentage and hydro companies used least 16 percentage of total assets as capital structure. Dividing the total debt into long term debt and current liabilities, Trading companies have used a minimum of six percent of long term debt, followed by manufacturing firms eight percent and hotel industry used a maximum 16 percentage of long term debt. Assets structure shows that the trading company used a maximum of 65 percent of total assets as current assets followed by manufacturing and hydro companies used a minimum of 15 percent of total assets. On an average hotel industry and hydro industry of Nepal uses a maximum of 71 percent of total assets as tangible assets but trading companies used a minimum of 35 percent of total assets as tangible assets. There is no investment in other/intangible assets in the non-financial industry except the hydro industry 14 percent of total assets. On average Nepalese non-financial companies uses 42 percent on current assets, 54 percent on intangible assets and 4 percent on other assets. The maximum percentage of total assets has been financed through equity in the hydropower companies and trading companies used a minimum percentage of equity financing. On average Nepalese non-financial sector's financial mix is fifty percent equity and fifty percent debt. The proportion of long term debt and current liabilities is 10 percent and 40 percent of total assets. It clarifies that portion of long term debt is very low in these sectors.

The basic components of efficiency are outputs and inputs. In this study, sales or revenue is used as output and material cost and labor cost or operating cost as input. The position of output, input, operating profit and net profit (amounts in Rs lakh) have been presented in the first section. The second section of Table 2 presents ratios of the concerned variables on sales.

Table 2

Measurement of Efficiency

\begin{tabular}{|c|c|c|c|c|c|c|}
\hline Variables & Hotel & $\mathrm{Mfg}$ & Hydro & Trading & Mean & $\mathrm{SD}$ \\
\hline \multicolumn{7}{|c|}{ In Rs (Lakh) } \\
\hline Output & 12403.5 & 32765.4 & 4404.1 & 46032.6 & 23207.6 & 16439.97 \\
\hline Inputs & 9200.51 & 26711.4 & 1227.6 & 43002.6 & 19339.3 & 16152.22 \\
\hline EBIT & 3202.99 & 6054.01 & 3176.5 & 3029.96 & 3868.31 & 1265.044 \\
\hline NPAT & 2023.41 & 4052.23 & 3063.96 & 256.22 & 2395.75 & 1405.316 \\
\hline \multicolumn{7}{|c|}{ In Ratio } \\
\hline Efficiency & 1.34813 & 1.22665 & 3.58757 & 1.07046 & 1.20002 & 1.067261 \\
\hline EBIT to sales & 0.25823 & 0.18477 & 0.72126 & 0.06582 & 0.16668 & 0.2564 \\
\hline $\mathrm{O}$ E to sales & 0.74177 & 0.81523 & 0.27874 & 0.93418 & 0.83332 & 0.2564 \\
\hline NPAT to sales & 0.16313 & 0.12367 & 0.69571 & 0.00557 & 0.10323 & 0.273135 \\
\hline
\end{tabular}

As observed in Table 2, output ranges from 4404.1 lakh (hydro) to Rs 46032.57 lakh (trading) and input ranges from Rs 1227.6 lakh (hydro) to 43002.61 lakh (trading). On average, Nepalese nonfinancial sectors generate annual sales of Rs 23207.57 lakh and incur annual operating expenses of Rs 19339.26 lakh. Efficiency ratio ranges from 1.07 in trading sectors to a maximum of 3.59 in hydropower companies. On average nonfinancial sectors of Nepalese listed companies generate twenty percent more output over their input costs as indicated by efficiency ratio 1.20 . The result shows that, on the basis of efficiency, Hydro is the most efficient non-financial sector which is followed by the Hotels and the trading sector as 
the least efficient sector in Nepal. The result is further justified by the EBIT to sales and NPAT to sales ratios.

Descriptive statistics of the nonfinancial industry has been presented in this part. Manufacturing and processing companies, hotels, hydropower companies, and trading companies are included as nonfinancial sectors in Nepal.

Table 3

Descriptive Statistics of Non-Financial Firms

\begin{tabular}{lrrrrr}
\hline Variables & $\mathrm{N}$ & Min & Max & Mean & SD \\
\hline LEV & 60 & .0251 & .8450 & .4535 & .2407 \\
EFF & 60 & 1.0223 & 7.2651 & 1.9039 & 1.3934 \\
SIZE & 60 & 15.8494 & & 22.9943 & 20.8598 \\
TAN & 60 & .0535 & 0.9806 & .5859 & .2681 \\
PROF & 60 & .0067 & .6658 & .1300 & .1258 \\
GROWTH & 60 & -.7996 & 1.0005 & .0353 & .2620 \\
\hline
\end{tabular}

Table 3 provides descriptive statistics for dependent variables and independent variables. The dependent variables are leverage (TD/TA) and efficiency (Sales/OE). The independent variables are size, tangibility, profitability, and growth. $\mathrm{N}$ is the number of observations. The table shows that the leverage ranges from 0.0251 to 0.8450 , leading to an average of 0.4535 . Similarly level of efficiency varies from 1.0223 to 7.2651 with an average of 1.904 . The size $\ln$ (Sales) ranges from 15.8494 to 22.9943 , leading to an average of 20.8598. The tangibility (tangible asset/total assets) varies from 0.0535 to 0.98 , with an average of 0.5859 or 58.59 percent. The sales growth varies from negative 0.7996 to 1.0005 , leading to an average of 0.2621 .

Having indicated the descriptive statistics, the Pearson Correlation Coefficients have been computed and results are presented in different tables. This table presents correlation coefficients among the variables used in this study. The dependent variables are LEV (TD/TA) i.e total debt/total assets and EFF (Sales/OE). The independent variables are SIZE, tangibility (TAN), profitability (PROF), GROWTH.

Table 4

Correlation Matrix of Non-Financial Institution

\begin{tabular}{lrrrrrr}
\hline Variables & LEV & EFF & SIZE & TAN & PROF & GROWTH \\
\hline LEV & 1 & & & & & \\
EFF & $-.659^{* *}$ & 1 & & & & \\
SIZE & $.657^{* *}$ & $-.563^{* *}$ & 1 & & & \\
TAN & $-.665^{* *}$ & $.381^{* *}$ & $-.600^{* *}$ & 1 & & \\
PROF & -0.014 & -0.132 & $.274^{*}$ & -0.21 & 1 & \\
GROWTH & 0.247 & -0.077 & $.454^{* *}$ & $-.277^{*}$ & 0.25 & 1 \\
\hline
\end{tabular}

**. Correlation is significant at the 0.01 level.

*. Correlation is significant at the 0.05 level. 
As observed from Table 4 there is a negative correlation between leverage and efficiency (-.659), tangibility and profitability (-.665) but positive relationship between leverage and size (.657), and growth (.247). It implies that higher the efficiency lower would be leverage. Similarly, an increase in the size of the business increases leverage. Likewise, there is a negative relationship between efficiency and size (-.563), efficiency and profitability (-.132), efficiency and growth (-.077) but a positive relationship between efficiency with tangibility (.381). It implies that the higher the size of the business higher would be the efficiency of the business. Similarly, an increase in profitability leads to a decrease in inefficiency. The sales growth is inversely related to efficiency. However, higher investment in tangible assets leads to the efficiency of firms. Size is negatively correlated with tangibility (-.600) but positively correlated with profitability and growth (.273 and .454). It implies that the increase in tangible assets increases the size of the business. However, the increase in the size of the business leads to increases in profitability as well as the growth of the business. Tangible assets are negatively correlated with profitability (-.21) and growth(-.277). It exhibits that higher investment in tangible assets decreases the profitability and growth of the business. Lastly, profitability is positively correlated with growth(.25). It shows that higher the profitability of the business, higher will be the growth of the business.

Having indicated the Pearson correlation coefficients, the regression analysis has been made and the results are presented. More specifically, it shows the regression of different independent variables on the dependent variable for Nepalese non-financial companies. First of all the impact of control variables on the dependent variable has been presented, the impact of leverage and control variables on efficiency and impact of efficiency and control variables on leverage has been presented.

Table 5

Estimated Regression Results of Size, Tangibility, Profitability, and Growth on the Efficiency of Nepalese Non-Financial Industry

\begin{tabular}{cccccccc}
\hline Result & Intercept & SIZE & TAN & PROF & GROWTH & $\mathrm{R}^{2}$ & F Value \\
\hline 1 & $12.280^{* *}$ & $-0.497^{* *}$ & & & & 0.317 & $26.952^{* *}$ \\
& $(6.127)$ & $(-5.192)$ & & & & & \\
2 & 0.714 & & $2.040^{* *}$ & & & 0.149 & $10.181^{* *}$ \\
& $(1.747)$ & & $(3.191)$ & & & & \\
3 & $2.094^{* *}$ & & & -1.463 & & 0.017 & 1.030 \\
& $(8.061)$ & & & $(-1.015)$ & & & \\
4 & $1.918^{* *}$ & & & & -0.410 & 0.006 & 0.347 \\
& $(10.508)$ & & & & $(-0.589)$ & & \\
5 & $11.124^{* *}$ & $-0.454^{* *}$ & 0.438 & & & 0.322 & $13.519^{* *}$ \\
& $(4.031)$ & $(-3.807)$ & $(0.613)$ & & & & \\
6 & 12.890 & -0.542 & 0.471 & -0.033 & 1.211 & 0.363 & $7.827^{* *}$ \\
& $(4.467)$ & $(-4.240)$ & $(0.667)$ & $(-0.027)$ & $(1.865)$ & & \\
\hline
\end{tabular}

a. Figures in parenthesis are t-values

b. The sign asterisk $(*)$ indicates that the result is significant at $5 \%$ and the double-asterisk $(* *)$ sign indicates that the result is significant at $1 \%$.

Result 1 to 4 in Table 5 shows the impact of size, tangibility, profitability and growth individually on efficiency. Result 5 has been developed to show the impact of size and tangibility which have a significant impact on efficiency. Finally, Result 6 shows the impact of all study variables on efficiency. The beta 
coefficients are negative for size and profitability. It implies that an increase in size and profitability decreases efficiency. The finding is similar to Margaritis and Psillaki (2007). Beta coefficients are positive for tangibility and growth. It implies that an increase in tangibility and growth increases efficiency. The finding is consistent with the results of Wiliamson (1967). The F-value of 7.827 is also significant at a $1 \%$ level of confidence indicates the fit of the model presented. $\mathrm{R}^{2}$ of 0.363 suggests that $36.3 \%$ of the firm efficiency can be explained by the variations in the whole set of independent variables.

Table 6

Estimated Regression Results of Leverage, Size, Tangibility, Profitability, and Growth on the Efficiency of Nepalese Non-Financial Industry

\begin{tabular}{crrrrrrrr}
\hline Result & Intercept & LEV & SIZE & TAN & PROF & GROWTH & R $^{2}$ & F Value \\
\hline \multirow{2}{*}{1} & $3.374^{* *}$ & $-3.366^{* *}$ & & & & & 0.348 & $31.42^{* *}$ \\
& $(11.055)$ & $(-5.606)$ & & & & & & \\
2 & $3.086^{*}$ & & -0.059 & & & & 0.017 & 1.022 \\
& $(2.543)$ & & $(-1.011)$ & & & & & \\
3 & 0.649 & & & $2.132^{* *}$ & & & 0.171 & $12.18^{* *}$ \\
& $(1.676)$ & & & $(3.489)$ & & & & \\
4 & $2.024^{* *}$ & & & & -1.181 & & 0.011 & 0.67 \\
& $(7.846)$ & & & & $(-0.819)$ & & & \\
5 & 1.886 & & & & & -0.394 & 0.05 & 0.315 \\
& $(10.346)$ & & & & & $(-0.562)$ & & \\
6 & $2.826^{* *}$ & $-2.97^{* *}$ & & 0.647 & & & 0.358 & $16.20^{* *}$ \\
7 & $(4.48)$ & $(-4.116)$ & & $(0.993)$ & & & & \\
7 & 1.305 & $-4.37^{* *}$ & $0.135^{*}$ & -0.011 & -2.113 & 0.475 & 0.425 & $8.143^{* *}$ \\
\hline
\end{tabular}

a. Figures in parenthesis are t-values

b. The sign asterisk $(*)$ indicates that the result is significant at $5 \%$ and double asterisk $(* *)$ sign indicates that the result is significant at $1 \%$

The regression result from Result 1 to 5 in Table 6 shows the impact of leverage, size, tangibility profitability, and growth individually on efficiency. Result 6 has been developed to show the impact of leverage, and tangibility which have a significant impact on efficiency. Finally, Model 7 shows the impact of all study variables on efficiency. The beta coefficients are negative for leverage, tangibility, and profitability. It implies that an increase in leverage decreases efficiency. The finding is similar to Margaritis and Psillaki (2007). An increase in leverage increases financial risk and decrease efficiency. An increase in tangibility decreases efficiency, the finding is opposed to the findings of Titman and Wessels (1988), Rajan and Zingales (1995) and Frank and Goyal (2003). It implies that over-investment on tangible assets decreases the overall efficiency of a firm. Beta coefficients are positive for Size and growth. It implies that an increase in size increases the efficiency. The finding is consistent with the results of Wiliamson (1967). Larger firms are expected to use better technology, more diversified and well managed. In the same way, an increase in growth increases efficiency, the coefficient of this variable is not significant in non-financial listed companies of Nepal. However beta coefficients are significant for the leverage, and tangibility. The F-value of 8.143 is also significant at a $1 \%$ level of confidence indicates the fit of the model presented. R2 of .475 suggests that $47.5 \%$ of the firm efficiency can be 
explained by the variations in the whole set of independent variables.

Table 7

Estimated Regression Results of Leverage, Size, Tangibility, Profitability, and Growth on the Efficiency of Nepalese Non-Financial Industry

\begin{tabular}{|c|c|c|c|c|c|c|c|}
\hline Result & Intercept & SIZE & TAN & PROF & GROWTH & $\mathrm{R}^{2}$ & F Value \\
\hline 1 & $\begin{array}{r}-1.637 * * \\
(-5.178)\end{array}$ & $\begin{array}{r}0.100 * * \\
(6.632)\end{array}$ & & & & 0.431 & $43.979 * *$ \\
\hline 2 & $\begin{array}{c}0.806 * * \\
(14.049)\end{array}$ & & $\begin{array}{l}-.604 * * \\
(-6.734)\end{array}$ & & & 0.439 & $45.350 * *$ \\
\hline 3 & $\begin{array}{c}0.457 * * \\
(10.089)\end{array}$ & & & $\begin{array}{r}-0.026 \\
(-0.104)\end{array}$ & & 0.000 & 0.011 \\
\hline 4 & $\begin{array}{c}0.445 * * \\
(14.529)\end{array}$ & & & & $\begin{array}{r}0.227 \\
(1.944)\end{array}$ & 0.061 & 3.777 \\
\hline 5 & $\begin{array}{r}-0.620 \\
(-1.592)\end{array}$ & $\begin{array}{r}0.062 * * \\
(3.694)\end{array}$ & $\begin{array}{l}-.385 * * \\
(-3.820)\end{array}$ & & & 0.547 & $34.440 * *$ \\
\hline 6 & $\begin{array}{r}-0.776 \\
(-1.958)\end{array}$ & $\begin{array}{c}0.073 * * \\
(4.150)\end{array}$ & $\begin{array}{l}-.399 * * \\
(-4.120)\end{array}$ & $\begin{array}{l}-.429 * * \\
(-2.487)\end{array}$ & $\begin{array}{r}-0.036 \\
(-0.401)\end{array}$ & 0.597 & $20.360 * *$ \\
\hline
\end{tabular}

a. Figures in parenthesis are t-values

b. The sign asterisk $(*)$ indicates that the result is significant at $5 \%$ and double asterisk $(* *)$ sign indicates that the result is significant at $1 \%$

Result 1 to 4 in Table 7 shows the impact of size, tangibility profitability and growth individually on leverage. Result 5 has been developed to show the impact of size and tangibility which have a significant impact on leverage. Finally, Result 6 shows the impact of all study variables on leverage. The beta coefficients are negative for tangibility, profitability, and growth on leverage. It implies that the impact of these variables on leverage is negative. An increase in tangibility, profitability, and growth decrease the leverage of the business. Beta coefficients are significant for size, tangibility, and profitability. The beta coefficient of growth is positive that indicates an increase in growth increase leverage. The finding is consistent with Rajan and Zingales (1995). The F-value of 20.360 is also significant at a $1 \%$ level of confidence indicates the fit of the model presented. R2 of 0.597 suggests that $59.7 \%$ of the firm leverage can be explained by the variations in the whole set of independent variables.

The results in Table 8 show that the beta coefficients are negative for efficiency, tangibility, and profitability on leverage. It implies that the impact of these variables on leverage is negative. An increase in efficiency decreases the leverage of the business. The finding is similar to Berger and Bonaccorsidipatti (2006). Increase in tangibility, decrease the leverage, the finding is similar to. An increase in profitability decreases the leverage. The finding is similar to Harris and Raviv (1991), Rajan and Zingales (1995), Myers (1984) and Myers and Majluf (1984). However beta coefficients are significant for efficiency, size, tangibility, and profitability. The beta coefficient of size and growth is positive that indicates an increase in size increase leverage. The finding is consistent with Rajan and Zingales (1995). It implies that large firms are in a better position to issue equity rather than debt. An increase in growth increases the leverage of business. The results are not consistent with Myers (1977); it implies that growing firms are in a better position to issue equity rather than debt. 
Table 8

Estimated Regression Results of Efficiency, Size, Tangibility, Profitability, and Growth on the Leverage of the Nepalese Non-Financial Industry

\begin{tabular}{crrrrrrrr}
\hline Result & Intercept & EFF & SIZE & TAN & PROF & GROWTH & R $^{2}$ & F Value \\
\hline \multirow{2}{*}{1} & $0.639^{* *}$ & $-0.103^{* *}$ & & & & & 0.348 & $31.42^{* *}$ \\
& $(14.88)$ & $(-5.606)$ & & & & & & \\
2 & $-0.411^{*}$ & & $0.042^{* *}$ & & & & 0.277 & $22.62^{* *}$ \\
& $(-2.257)$ & & $(4.756)$ & & & & & \\
3 & $0.733^{* *}$ & & & $-0.5^{* *}$ & & & 0.307 & $26.14^{* *}$ \\
& $(11.817)$ & & & $(-5.113)$ & & & & \\
4 & $0.422^{* *}$ & & & & 0.035 & & 0 & 0.019 \\
& $(9.72)$ & & & & $(0.139)$ & & & \\
5 & $0.442^{* *}$ & & & & & 0.035 & 0.06 & 3.746 \\
& $(9.72)$ & & & & & $(0.139)$ & & \\
6 & 0.016 & -0.065 & 0.036 & -0.34 & & & 0.671 & $38.67^{* *}$ \\
7 & $(0.121)$ & $(-4.445)$ & $(5.983)$ & $(-4.509)$ & & & & \\
7 & 0.011 & $-0.067 * *$ & $0.04^{* *}$ & $-0.36^{* *}$ & $-0.43^{* *}$ & 0.04 & 0.714 & $27.50^{* *}$ \\
\hline
\end{tabular}

a. Figures in parenthesis are t-values

b. The sign asterisk $(*)$ indicates that the result is significant at $5 \%$ and double asterisk $(* *)$ sign indicates that the result is significant at $1 \%$

\section{CONCLUSIONS}

Assets structure of Nepalese nonfinancial listed companies comprises of more amount of tangible assets followed by current assets and negligible investment in other intangible assets. The result implies that more investment in fixed assets, lower investment indirect income-generating assets and low growth prospects due to lower investment in intangible assets. Debt and equity are equally distributed in non-financial firms of Nepal. Highly levered firms are less efficient and efficient firms use more equity financing. There is a significant negative relationship between leverage and efficiency means an increase in leverage to increase the financial risk and decrease efficiency. A negative relationship between leverage and tangibility justify that tangible/ fixed assets are financed through equity rather than the debt due to financial risk. The actual earning rate on a total investment of non-financial firms is lower as indicated by the negative relationship between leverage and profitability. The relationship between efficiency and size is also negative that means increasing sales decrease the efficiency which is against the existing international literature of finance. A negative relationship between size and tangibility justify that over-investment in fixed assets decrease the sales of non-manufacturing firms in Nepal. There is a positive relationship between leverage and size that justify that these firms use more debt financing to manage current assets and increase the sales of the firms. A positive relationship between efficiency and tangibility justify that more investment in tangible assets increases the firms' efficiency. An increase in sales increases the growth rate of nonfinancial firms as suggested by a positive relationship between size and growth. There is no consistency on the impact of size, tangibility, profitability, and growth on 
leverage among four industries within nonfinancial firms. The major conclusion of this study is that size, tangibility, profitability, and growth are the significant factors in determining the efficiency and leverage of Nepalese non-financial firms. The firms having high leverage are less efficient and more efficient firms use low leverage. The conclusions are consistent with Titman and Wessels(1988), Rajan and Zingales(1995), Frank and Goyal (2003), Williamson (1967). Similarly, the empirical research findings are also consistent with Berger and Patti (2006) and Myers (1984).

One limitation of this study is the inclusion of the limited variables to measure the efficiency of the firms. As the study is based on panel data, the econometric methodology like least squares dummy variable (LSDV) model, fixed and random effects panel data models and Data envelopment analysis (DEA) were not considered in the study. Future research needs to include additional variables and fulfill the above-mentioned model too. Furthermore, the study only includes some non-financial institution, future empirical research needs to concentrate on all the listed companies of NEPSE. Lastly, there are many non-listed companies whose capital structure and efficiency need to be analyzed in the future.

\section{REFERENCES}

Ahmad, F., Haq, J. U., Nasir, R. U., Ali, M., \& Ullah, W. (2011). Extension of determinants of capital structure: Evidence from Pakistani non-finanial firms. African Journal of Business Management, 5 (28), 11375-11385.

Akintoye, I. R. (2008). Sensitivity of performance to capital structure. European Journal of Social Science, 7 (1), 163-144.

Ansah-Adu, K., Andoh, C., \& Abor, J. (2012). Evaluating the cost efficiency of insurance companies in Ghana. Journal of Risk Finance, 13(1), 61-76.

Basnet, A. (2015). Capital structure of financial firms: Evidence from Nepalese commercial banks (Unpublished master thesis). Hanken School of Economics, Vassa.

Berger, A., \& Bonaccorsidipatti, E. (2006). Capital structure and firm performance: A new approach to testing agency theory and an application to the banking industry. Journal of Banking \& Finance, 30(4), 1065-1102.

Bhattarai, Y. (2016).Capital structure and firm performance: Evidence from Nepalese manufacturing companies. Journal for Studies in Management and Planning, 2(3), 138-150.

Chechet, I. L., \& Olayiwola, A. B. (n.d.). Capital structure and profitability of Nigerian quoted firms: The agency cost theory perspective. Retrieved from http://www.aijssnet.com/journals/Vol_3_No_1_January_2014/13.pdf

Coelli, T., Rao, D.S.P. \& Battese, G.E. (1998). An introduction to efficiency and productivity analysis. Boston: Kluwer Academic.

Dare, F. D., \& Sola, O. (2010). Capital structure and corporate performance in Nigerian petroleum industry: Panel data analysis. Journal of Mathematics and Statistics, 6(2), 168-173.

Dogan, M. (2013). Does firm size affect the firm profitability? Evidence from Turkey. Research Journal of Finance and Accounting, 4, 53-59.

Friend, I., \& Lang, L.H. (1988). An empirical test of the impact of managerial self-interest on corporate capital structure. Journal of Finance, 43(9), 271-281.

Goyal, A.M. (2003). Impact of capital structure on performance of listed public-sector banks in India. International Journal of Business and Management Invention, 2(10), 35-43.

Idode, P.E, Adeleke, T.M., Ogunlowore, A.J., \& Ashogbon, O.S. (2014). Influence of capital structure on profitability: Empirical evidence from listed Nigerian banks, 16 (11), 22-28.

Iorpev, L., \& Kwanum, I.M. (2012). Capital structure and firm performance: Evidence from manufacturing companies in Nigeria. International Journal of Business and Management Tomorrow, 2(5), 1-5. 
Kazempour, M., \& Aghaei, M. A. (2015). Capital structure and firms performance in Tehran Stock Exchange. International Journal of Management, Accounting and Economics, 2(2), 149-152.

Maharjan, A. (2017). Relationship between capital structure and profitability: A study of Nepalese commercial banks. Nepalese Journal Management, 4(2), 96-111.

Margaritis, D., \& Psilaki, M. (2007). Capital structure and firm dfficiency. Journal of Business Finance and Accounting , 34 (9), 1447-1469.

Myers, S. (1977). Determinant of economic borrowing . Journal of Financial Economics, 5, 147-175.

Myers, S., \& Majluf, N. (1984). Corporate financing and investment decision when firms have information that investors do not have. Journal of Financial Economics , 13, 187-221.

Opoku, E. F., Adu, J. K., \& Anarfi, B. O. (2013). The impact of capital structure and profitability of listed banks on the Ghana Stock Exchange. Social and Basic Sciences Research Review, 1(2), 74-91.

Poudel, R. B. (1994). Industrial finance in Nepal (Unpublished PhD thesis). Faculty of Management, Tribhuvan University. .

Pouraghajan, A., Malekian, E., Emamgholipour, M., Lotfollahpour, V., \& Bagheri, M. M. (2012). The relationship between capital structure and firm performance evaluation measures: Evidence from the Tehran stock exchange . International Journal of Business and Commerce , 1 (9), 166-181.

Prahalathan, B., \& Rajan, R.P.C. (2011). The impact of capital structure-choice on firm performance: Emperical investigation of listed companies in Colombo stock exchange, Srilanka. International Journal of Research in Commerce and Management, 2(4), 12-17.

Rajan, R. G., \& Zingales, L. (1995). What do we know about capital structrure ? Some evidence from international data. Journal of Finance, 50(5), 1421-1460.

Rogers, M. (1998). The definition and measurement of productivity. The university of Melbourne, Australia, Melbourne institute of applied economics and social research. Working paper 9/98.

Saeedi, A. \& Mahmoodi, I.(2011). Capital structure and firm performance: Evidence from Iranian companies. International Research Journal of Finance and Economics, 70, 20-29.

Taub, A. J. (1975). Determinants of the firm's capital structure. Review of Economics and statistics, 57(5), 410-416.

Titman, S., \& Wessels, R. (1988). The determinant of capital structure choice. Journal of Finance , 43, 1-19.

Warokka, A ., Herrera, J ., \& Abdullah, H . (2011).East Asian crporate governance: A test of the relation between capital structure and firm performance. International Journal of Economics and Finance Studies, 3(2),1-10. Retrieved from https://dergipark.org.tr/en/pub/ijefs/issue/26155/275470

Williamson, O. (1967). Hierarchical control and optimum firm size. Journal of Political Economy, 75. Retrieved from https://EconPapers.repec.org/RePec.ucp.jpolec.v:75:y:1967

Yahyazadehfar, M., Shams, SH., \& Matan, M. (2010). Relationship of firm characteristics with capital structure in the companies listed in Tehran stock exchange. Accounting and Auditing Research, 2(8).

Zeitun, R., \& Tian, G. G. (2007). Capital structure and corporate performance: Evidence from Jordan. Australasian Accounting Business and Finance Journal, 1(4), 40-61. 


\section{APPENDIX I}

\section{List of Sample Non Financial Companies Being Selected for the Study Along with the Study Period and Number of Observations.}

\begin{tabular}{|c|c|c|c|c|}
\hline S. No. & Group & Name of companies & Study period & Observations \\
\hline 1 & Hotel & Soaltee Hotel Limited (SHL) & $2013 / 14-2017 / 18$ & 5 \\
\hline 2 & Hotel & Taragaun Hyatt Regency Hotel (TRH) & $2012 / 13-2017 / 18$ & 6 \\
\hline 3 & Hotel & Oriental/Radison Hotel Limited (OHL) & $2014 / 15-2017 / 18$ & 4 \\
\hline 4 & Manufacturing & Unilever Nepal Limited (UNL) & $2015 / 16-2017 / 18$ & 3 \\
\hline 5 & Manufacturing & Nepal Lube Oil (NLO) & $2016 / 17-2017 / 18$ & 2 \\
\hline 6 & Manufacturing & Bottlers Nepal Limited Balaju (BNL) & $2016 / 17-201 / 18$ & 2 \\
\hline 7 & Manufacturing & Bottlers Nepal Terai Limited (BNT) & $2015 / 16-2017 / 18$ & 3 \\
\hline 8 & Manufacturing & Himalayan Distillary Limited (HDL) & 2013/14-2017/18 & 5 \\
\hline 9 & Hydro & $\begin{array}{l}\text { Arun Valley Hydropower Company } \\
\text { (AHPC) }\end{array}$ & $2015 / 16-2017 / 18$ & 3 \\
\hline 10 & Hydro & $\begin{array}{l}\text { Butwal power Company Limited } \\
\text { (BPCL) }\end{array}$ & $2016 / 17-2017 / 18$ & 2 \\
\hline 11 & Hydro & $\begin{array}{l}\text { Chilime hydropower Company Limit- } \\
\text { ed (CHCL) }\end{array}$ & $2015 / 16-2017 / 18$ & 3 \\
\hline 12 & Hydro & $\begin{array}{l}\text { National Hydropower Company Limit- } \\
\text { ed (NHPC) }\end{array}$ & $2015 / 16-2017 / 18$ & 3 \\
\hline 13 & Hydro & $\begin{array}{l}\text { Sanima mai Hydropower Company } \\
\text { (SHPC) }\end{array}$ & $2016 / 17-2017 / 18$ & 2 \\
\hline 14 & Hydro & Ridi Hydropower company (RHPC) & $2015 / 16-2017 / 18$ & 3 \\
\hline 15 & Trading & Salt Trading Corporation (STC) & $2004 / 05-2017 / 18$ & 14 \\
\hline \multicolumn{4}{|c|}{ Total number of observations } & 60 \\
\hline
\end{tabular}

